\title{
Galactosamine induced hepatitis induces a reduction in hepatocyte epidermal growth factor receptors
}

\author{
D A Vesey, A C Woodman, H J F Hodgson
}

\begin{abstract}
The rapid regenerative response of the rat liver to partial hepatectomy is associated with a decline in liver epidermal growth factor receptor numbers which implies that ligand epidermal growth factor receptor interactions maybe important in initiating and/or modulating this process. The proliferative process in toxic hepatitis (where in contrast with partial hepatectomy the majority of hepatocytes have been exposed to damaging influences) has been less widely investigated. We studied the DNA synthetic response of rat livers to toxic injury induced by a 350 or $800 \mathrm{mg} / \mathrm{kg}$ ip injection of galactosamine and that caused by $70 \%$ hepatectomy, comparing the changes in epidermal growth factor receptor status. Both resulted in down regulation of epidermal growth factor receptors, suggesting similar ligand epidermal growth factor receptor binding occurs during the proliferative response after galactosamine administration and after partial hepatectomy. In vitro studies on isolated hepatocytes showed that epidermal growth factor receptor down regulation was not a direct effect of galactosamine on hepatocyte membranes.
\end{abstract}

The liver has a remarkable capacity to regenerate after viral and toxic hepatitis, and surgical resection. ${ }^{1}$ Hepatocyte proliferation takes place by division of existing adult hepatocytes, but the factors initiating this proliferation are complex and incompletely understood. ${ }^{2}$ A significant early event in hepatic regeneration, studied in rats after $70 \%$ partial hepatectomy, is down regulation of the epidermal growth factor receptor. ${ }^{3-7}$ In vitro studies have clearly shown that the addition of the epidermal growth factor to hepatocyte membranes and hepatocytes causes epidermal growth factor receptor phosphorylation and down regulation, events which lead to stimulation of hepatocyte DNA synthesis implying that the epidermal growth factor receptor is involved in initiation of hepatic regeneration in vivo. ${ }^{5-8}$ TGF- $\alpha$, a small polypeptide with a marked structural homology to epidermal growth factor also interacts with the epidermal growth factor receptor and can stimulate DNA synthesis in hepatocytes in culture. $^{9-11}$ Unlike the epidermal growth factor, generation of TGF- $\alpha$ has been shown within the liver after partial hepatectomy, and therefore maybe the true mediator of the observed changes in the epidermal growth factor receptor. ${ }^{+1112}$

Alternative models for investigating hepatic regeneration include chemical damage. ${ }^{131+}$ D-galactosamine induces hepatitis within 24-48 hours of administration, producing histological damage similar to that of human viral hepatitis. ${ }^{15}$ The mode of action involves intracellular accumulation of galactosamine-1-phosphate and inhibition of uridine diphosphate-glucose pyrophosphatase which results in the depletion in uridine intermediates and subsequently depression of uracil nucleotide dependent synthesis of macromolecules - for example, mRNAs. ${ }^{16}$ It is not clear whether the regenerative processes after diffuse damage to the liver parenchyma are the same as those after partial resection of the liver. After resection the surviving cells are 'normal' whereas after toxic damage the surviving cells have been exposed to a chemical agent, and may show functional abnormalities. We therefore studied epidermal growth factor receptor down regulation after galactosamine induced hepatitis in rats, and compared those membrane changes with those induced by partial resection. In addition we studied the changes in epidermal growth factor receptors induced by galactosamine in primary cultures of rat hepatocytes and compared those with in vitro effects of the epidermal growth factor.

\section{Methods}

\section{MATERIALS}

$\left[6-{ }^{3} \mathrm{H}\right]$-thymidine (specific activity $25-30 \mathrm{Ci}$ mmol) and carrier free $\mathrm{Na}^{125} \mathrm{I}$ were obtained from Amersham International PLC, Amersham, Bucks, UK. William's medium E, fetal bovine serum, penicillin/streptomycin, fungizone (amphotericin B), gentamycin, Nunclon microwell plates were obtained from Gibco Ltd, Paisley, Renfrewshire, Scotland, UK. Twenty four well Falcon tissue culture plates were from Flow Laboratories Ltd, Ayrshire, Scotland, UK. Insulin (human, monocomponent, Actrapid) was purchased from Novo, Copenhagen, Denmark. Collagenase (Clostridium histolyticum) was purchased from Boehringer Mannheim (UK) Ltd, East Sussex, UK. Other reagents and chemicals were from Sigma Chemical Company or BDH Chemicals, both of Poole, Dorset, UK. Murine epidermal growth factor (Collaborative 
Research, tissue culture grade) was obtained from Universal Biologicals, London, UK, or purified from mouse submaxillary glands according to the method of Savage and Cohen 1972. ${ }^{17}$

\section{ANIMAL TREATMENT}

All experiments were carried out on male August rats (250-300 g) supplied by the National Institute of Medical Research, Mill Hill, London, UK. They were maintained under conditions of controlled temperature and lighting with access to food and water ad libitum. All procedures were carried out under ether anaesthesia between 9 and $11 \mathrm{am}$. Seventy per cent hepatectomy was performed as described by Higgins and Anderson. ${ }^{18}$ Rats received a single ip injection of $\mathrm{D}$-galactosamine, dissolved in saline, at 350 or $800 \mathrm{mg} / \mathrm{kg}$ body weight. Control rats received an equivalent injection of saline. Galactosamine treated rats were killed at either 24 or 48 hours and those after hepatectomy at 24 hours. One hour before being killed rats received an ip injection of ${ }^{3} \mathrm{H}$-thymidine $(0.5 \mu \mathrm{Ci} / \mathrm{g}$ body weight). Rats were killed one hour later by exsanguination under ether anaesthesia, the liver perfused in situ with ice cold saline and livers rapidly removed. Small sections of liver were formalin fixed for histology and frozen for measurement of thymidine incorporation, and the remaining tissue used to prepare liver cell plasma membranes. Blood samples taken were allowed to clot at $10^{\circ} \mathrm{C}$ for four hours, serum separated, and stored at $-20^{\circ} \mathrm{C}$ for subsequent analysis of serum enzyme concentrations.

\section{CELL CULTURE}

Adult rat hepatocytes were isolated using a modification of the two step in situ collagenase perfusion of Berry and Friend. ${ }^{1920}$ Eighty to ninety per cent of hepatocytes obtained were viable (trypan blue exclusion). Cells were resuspended at $3 \times 10^{5}$ or $2 \times 10^{5}$ viable cells $/ \mathrm{ml}$ in William's E medium w/o L-glutamine, supplemented penicillin $(200 \mathrm{IU} / \mathrm{ml})$; streptomycin (200 IU/ml); gentamycin $(80 \mu \mathrm{g} / \mathrm{ml})$; fungizone $(1.25 \mu \mathrm{g} / \mathrm{ml}) ; 5 \%(\mathrm{v} / \mathrm{v})$ heat inactivated fetal bovine serum and dexamethazone $\left(10^{-8} \mathrm{M}\right)$ [plating medium] and seeded on rat tail collagen (type-1) coated plates, at densities of $75 \times 10^{3} /$ $\mathrm{cm}^{2}$ in Falcon 24 well tissue culture plates or at $71 \times 10^{3} / \mathrm{cm}^{2}$ in Nucleon 96-well microwell plates. Cells were maintained at $37^{\circ} \mathrm{C}$ in an atmosphere of $5 \% \mathrm{CO}_{2} / 95 \%$ air with $>95 \%$ humidity.

\section{PLASMA MEMBRANE PREPARATION}

Rat liver plasma membranes prepared by conventional methods Arnonson and Touster (1974), ${ }^{21}$ Hubbard et al (1983). ${ }^{22}$ They were resuspended in $5 \mathrm{mM}$ Hepes buffer $\mathrm{pH} 7.5$ at approximately $5 \mathrm{mg} / \mathrm{ml}$ and stored in liquid nitrogen until used. Protein concentration was determined by a modification of the method of Lowry $^{23}$ with bovine serum albumin as a standard.
IODINATION OF EPIDERMAL GROWTH FACTOR Epidermal growth factor was iodinated by a modification of the chloramine- $T$ method, as previously described, ${ }^{24}$ to give a specific activity of between 15 to $60 \mu \mathrm{Ci} / \mu \mathrm{g}$.

\section{EPIDERMAL GROWTH FACTOR BINDING STUDIES}

\section{On hepatocytes}

Binding studies on whole cells were carried out in 24 well tissue culture plates. After four hours allowed for the attachment of the cells the medium was removed and the new medium containing growth factors and/or galactosamine and/or uridine added at concentrations indicated in the Tables. At various times a plate of cells was cooled on ice, the medium removed, and cells washed two times with ice cold William's medium $\mathrm{E}$ containing $0.1 \%(\mathrm{w} / \mathrm{v})$ bovine serum albumin and $20 \mathrm{mM}$ Hepes (binding medium). Cells incubated with epidermal growth factor were washed twice with an acid buffer $(50 \mathrm{mM}$ glycine and $0 \cdot 1 \mathrm{M}$ sodium chloride, $\mathrm{pH} 4$ ) between the binding medium washes to remove surface bound epidermal growth factor. Binding medium containing ${ }^{125} \mathrm{I}$ epidermal growth factor (approximately $4 \times 10^{5} \mathrm{cpm} / 0.5 \mathrm{ml}$ ) was then added to the cells which were incubated on ice for 2.5 hours. After this the cells were washed four times with ice cold Hanks balanced salt solution containing bovine serum albumin $0.1 \%(\mathrm{w} / \mathrm{v})$ and treated twice with $0.6 \mathrm{ml}$ of $0.2 \mathrm{M}$ acetic acid containing $\mathrm{NaCl}(0.5 \mathrm{M})$ for six minutes. The acid washes were combined and the radioactive content determined in a gamma counter. Over $95 \%$ of surface bound radioactivity was removed from the cell in this way without removing iodine from epidermal growth factor. Internalisation of ${ }^{125} \mathrm{I}$ epidermal growth factor during the incubation at $4^{\circ} \mathrm{C}$ was minimal. Non-specific binding was determined at each point by inclusion of a $0.5 \mu \mathrm{g}$ of unlabelled epidermal growth factor in replica wells. This was subtracted from total counts bound to obtain specific binding. Points represent the means of triplicate observations.

\section{On plasma membranes}

Increasing amounts of ${ }^{125} \mathrm{I}$ epidermal growth factor $(50-3000 \mathrm{fmol})$ were incubated with between 60 and $100 \mu \mathrm{g}$ membrane protein for 60 minutes at room temperature in Hepes buffer $(20$ $\mathrm{mM} \mathrm{pH} 7 \cdot 5)$ containing $0.1 \%(\mathrm{w} / \mathrm{v})$ bovine serum albumin in a total volume of $0.2 \mathrm{ml}$ in microfuge tubes. The tubes were then centrifuged for four minutes at $15000 \mathrm{~g}$ in a microfuge and the supernatant and pellet separated. Both were counted in a gamma counter. Non-specific binding was determined in the presence of $1 \mu \mathrm{g}$ unlabelled epidermal growth factor. Measurements were made in triplicate. Binding data were analysed by an iterative non-linear least squares correlation using the computer program GraphPAD Inplot and fitted to a 2 parameter model which identified a single low affinity binding site. 
TABLE I DNA synthesis in the liver of rats in response to partial hepatectomy and galactosamine treatment

\begin{tabular}{lcc}
\hline Treatment & $\begin{array}{c}{ }^{3} \mathrm{H} \text {-thymidine incorporation } \\
\left(d p m \times 10^{-4} / \mathrm{g} \text { liver }\right)^{\star}\end{array}$ & $n$ \\
\hline Sham/saline & $9 \cdot 1(1 \cdot 5)$ & 6 \\
Hepatectomy 24 h & $535 \cdot 7(38 \cdot 8)$ & 6 \\
GalN 24 h $\dagger$ & $20 \cdot 0(1 \cdot 4)$ & 6 \\
GalN 48 h $\dagger$ & $229 \cdot 0(14 \cdot 8)$ & 6 \\
GalN 48 h $\ddagger$ & $80 \cdot 7(4 \cdot 5)$ & 4 \\
\hline
\end{tabular}

${ }^{\star}$ Mean $(\mathrm{SEM}) ;$ †GalN dose $800 \mathrm{mg} / \mathrm{kg} ;$;GalN dose $350 \mathrm{mg} / \mathrm{kg}$.

\section{ASSESSMENT OF DNA REPLICATION}

In vitro

DNA synthesis was measured by assessment of ${ }^{3} \mathrm{H}$-thymidine incorporation into cell DNA. Twenty hours after seeding, the medium was changed and replaced with either plating medium alone, or plating medium containing insulin $\left(10^{-7} \mathrm{M}\right)$ and epidermal growth factor $(20 \mathrm{ng} / \mathrm{ml})$ with or without galactosamine $(0 \cdot 05-$ $1 \mathrm{mM})$ and/or uridine $(0.05-1 \mathrm{mM}) .{ }^{3} \mathrm{H}$ thymidine $(2 \mu \mathrm{Ci} /$ well $)$ was included in the cultures from 28 hours after plating. The amount of ${ }^{3} \mathrm{H}$-thymidine incorporated was assessed biochemically as described by Selden and Hodgson $(1989)^{19}$ between 44 and 48 hours after seeding. Each point was assayed in quadruplicate.

In vivo

${ }^{3} \mathrm{H}$-thymidine incorporation into liver DNA was measured biochemically by a modification of the method of Munro and Fleck $1966 .{ }^{25} \operatorname{Liver}(0.4 \mathrm{~g})$ was homogenised in $5 \mathrm{ml}$ ice cold $5 \mathrm{mM}$ Hepes buffer $\mathrm{pH} .7 .5$ for 30 seconds with a PotterElvehjem homogeniser. The homogenate was mixed with $5 \mathrm{ml}$ ice cold $0.6 \mathrm{M}$ perchloric acid and allowed to stand for 10 minutes on ice. The precipitate was centrifuged at $1500 \mathrm{~g}$ for 20 minutes and the pellet washed twice with $0.2 \mathrm{M}$ perchloric acid by repeated homogenisation and centrifugation. After the final wash the pellet was drained, solubilised in $4 \mathrm{ml} 0.3 \mathrm{M} \mathrm{KOH}$ and incubated for 1.5 hours in a $37^{\circ} \mathrm{C}$ water bath. Samples were cooled on ice for 10 minutes and $4 \mathrm{ml} 1 \cdot 2 \mathrm{M}$ perchloric acid added to reprecipitate. The tubes were left a further 10 minutes before centrifugation as above. The pellet was washed twice with $0.2 \mathrm{M}$ perchloric acid and the final pellet containing DNA heated to $80^{\circ} \mathrm{C}$ for 20 minutes in $4 \mathrm{ml} 0.5 \mathrm{M}$ perchloric acid to hydrolyse DNA. Fifty microlitres of supernatant was counted for tritium in $1 \mathrm{ml}$ Optiphase safe scintillant (Pharmacia-LKB).

\section{Results}

IN VIVO EFFECTS OF PARTIAL HEPATECTOMY AND GALACTOSAMINE LIVER PROLIFERATION

Preliminary experiments indicated that the maximum changes in epidermal growth factor binding and DNA synthesis occurred 24 hours after partial hepatectomy but 48 hours after galactosamine administration. Comparisons between the effect of these two procedures were made at the time of peak DNA synthesis.

Twenty four hours after hepatectomy there
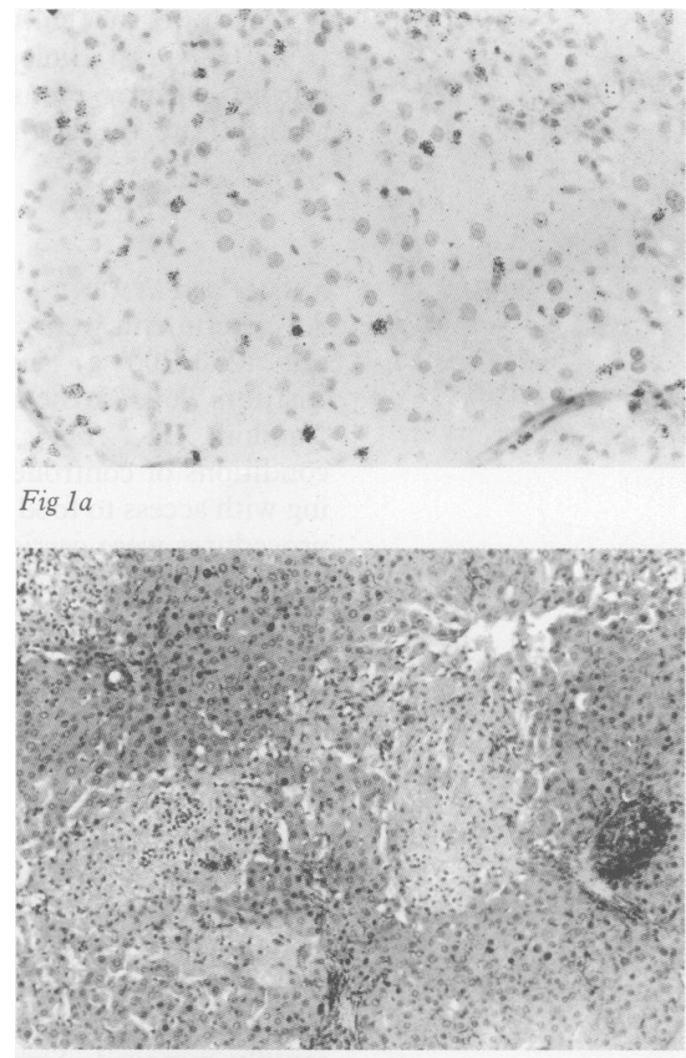

Fig 16

Figure 1: Photomicrographs of liver sections 48 hours after galactosamine injections. (a) Autoradiography to show ${ }^{3} \mathrm{H}$ thymidine incorporation in hepatocyte nuclei ( $350 \mathrm{mg} / \mathrm{kg}$ ). (b) A section showing wide spread areas of necrotic tissue after administration of $800 \mathrm{mg} / \mathrm{kg}$ galactosamine.

was a marked increase in DNA synthesis compared with sham operated animals. The mean increase in DNA synthesis, as assessed by ${ }^{3} \mathrm{H}$-thymidine incorporation into DNA, was approximately 60 -fold (Table I).

In animals killed 48 hours after receiving 350 $\mathrm{mg} / \mathrm{kg}$ body weight galactosamine there was a nine-fold increase in DNA synthesis compared with animals receiving saline alone (Table I).

In animals killed 48 hours after receiving 800 $\mathrm{mg} / \mathrm{kg}$ galactosamine, the level of incorporation of $3 \mathrm{H}$-thymidine into liver was 25 -fold greater than in control animals. This increase had commenced by 24 hours, with levels of incorporation at this time being twice that in controls (Table I).

There was no difference in liver DNA ${ }^{3} \mathrm{H}$ thymidine incorporation at 48 hours between sham operated animals and those receiving saline.

LIVER DAMAGE

The histological appearance of tissue taken 48 hours after administration of galactosamine at a dose of $350 \mathrm{mg} / \mathrm{kg}$ showed the presence of diffusely scattered swollen and vacuolated hepatocytes. There was little lymphocytic cell infiltration. Incorporation of ${ }^{3} \mathrm{H}$-thymidine was predominantly into the nuclei of hepatocytes (Fig la). At a dose of $800 \mathrm{mg} / \mathrm{kg}$ body weight patchy necrotic areas were wide spread (Fig lb).

Glutamic oxaloacetic transaminase (GOT/ AST: EC2.6.1.1) concentrations were substan- 

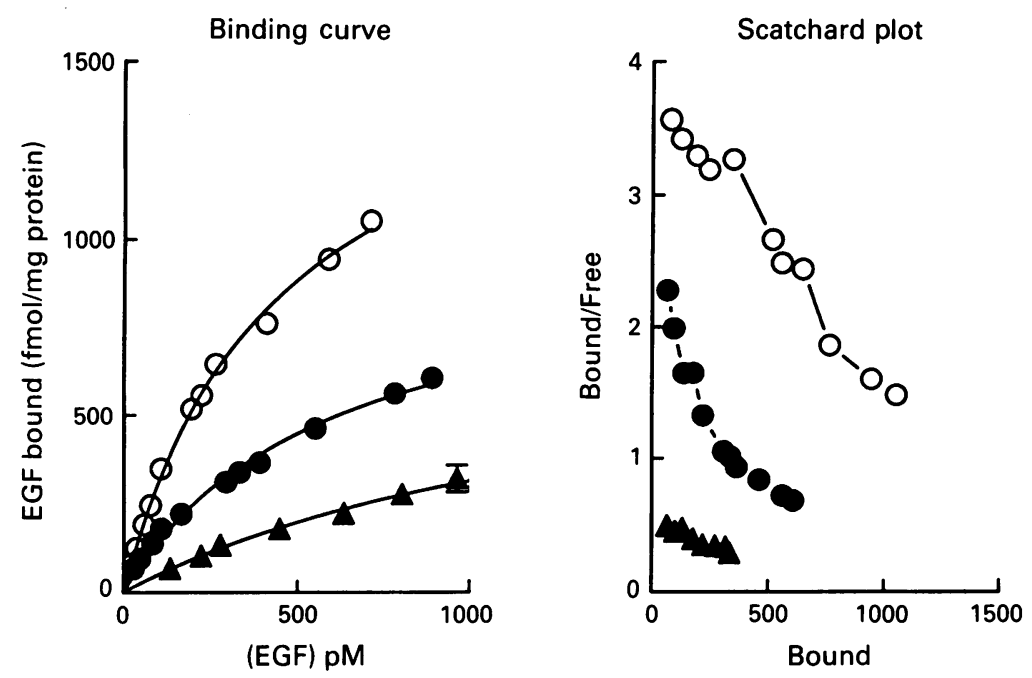

Figure 2: Effect of GaIN treatment on liver plasma membrane EGF receptors. Binding of ${ }^{125} I-E G F$ by plasma membranes isolated from the liver of rats 48 hours after administration of saline $(\bigcirc)$ or GalN, $350 \mathrm{mg} / \mathrm{kg}(\mathrm{O}), 800 \mathrm{mg} / \mathrm{kg}(\mathbf{\Delta})$. Iterative non-linear least square correlation was used for curve fitting. Saturation binding curves and Scatchard analysis are shown and calculated parameters are in Table II. Membranes were prepared by the method of Aronson and Touster, 1974. Axis marked [EGF]pM represents measured free ligand concentration (pico molar) and that marked bound EGF fmol/mg protein. Regression analysis: $r^{2}$ values were above 0.98. Each point is the mean of triplicate measurements. The SE of each point was below $10 \%$.
TABLE III Effect of galactosamine and uridine on DNA synthesis of hepatocytes in culture

\begin{tabular}{|c|c|}
\hline Treatment & $\begin{array}{l}{ }^{3} \mathrm{H} \text {-thymidine incorporation } \\
\left(\mathrm{dpm} \times 10^{-3} / 20000 \text { cells }\right)\end{array}$ \\
\hline $\begin{array}{l}\text { D } \\
\text { D I } \\
\text { D IE } \\
\text { D+G }(1 \mathrm{mM}) \\
\text { D IE+G }(1 \mathrm{mM}) \\
\text { D IE+G }(0.5 \mathrm{mM}) \\
\text { D IE+G }(0.05 \mathrm{mM}) \\
\text { D+U }(0.5 \mathrm{mM}) \\
\text { D IE+U }(5 \mathrm{mM}) \\
\text { D IE+U }(0.5 \mathrm{mM}) \\
\text { D IE+U }(0.05 \mathrm{mM}) \\
\text { D+G }(1 \mathrm{mM})+\mathrm{U}(0.5 \mathrm{mM}) \\
\text { D IE+G }(1 \mathrm{mM})+\mathrm{U}(5 \mathrm{mM}) \\
\text { D IE+G }(1 \mathrm{mM})+\mathrm{U}(0.5 \mathrm{mM}) \\
\text { D IE+G(1 mM)+U }(0.05 \mathrm{mM})\end{array}$ & $\begin{array}{l}29 \cdot 3(2 \cdot 4) \\
43 \cdot 2(2 \cdot 2) \\
79 \cdot 2(5 \cdot 2) \\
15 \cdot 7(5 \cdot 6) \\
25 \cdot 9(3 \cdot 3) \\
48 \cdot 4(4 \cdot 9) \\
77 \cdot 5(8 \cdot 6) \\
28 \cdot 5(1 \cdot 8) \\
35 \cdot 0(3 \cdot 8) \\
92 \cdot 9(11 \cdot 3) \\
93 \cdot 0(11 \cdot 4) \\
33 \cdot 6(6 \cdot 3) \\
53 \cdot 8(3 \cdot 3) \\
76 \cdot 9(5 \cdot 0) \\
66 \cdot 5(6 \cdot 9)\end{array}$ \\
\hline
\end{tabular}

Data are expressed as the mean and standard deviation (SD) of quadruplicated measurements from a typical experiment. The results were confirmed in two additional experiments.

$\mathrm{D}=$ dexamethazone $\left(10^{-8} \mathrm{M}\right) ; \mathrm{E}=\mathrm{EGF}(20 \mathrm{ng} / \mathrm{ml}) ; \mathrm{I}=$ insulin $\left(10^{-7} \mathbf{M}\right) ; \mathrm{G}=$ galactosamine; $\mathrm{U}=$ uridine.

TABLE IV Effect of GalN bv itself or in combination with uridine on ${ }^{125} I-E G F$ binding to, and viability of, hepatocytes in culture

\begin{tabular}{|c|c|c|c|}
\hline \multirow[b]{2}{*}{ Treatment } & \multicolumn{3}{|c|}{$\begin{array}{l}125 \text { I-EGF bound ( } \mathrm{mmol} / 1.5 \times 10^{5} \text { cells) } \\
\text { at different times after start of treatment } \\
\text { [cell viability] }\end{array}$} \\
\hline & 4 hours & 20 hours & 47 hours \\
\hline Control & $\begin{array}{c}26 \cdot 2(0 \cdot 4) \\
{[100]}\end{array}$ & $\begin{array}{c}14 \cdot 1(0 \cdot 9) \\
{[>95]}\end{array}$ & $\begin{array}{c}10 \cdot 2(0 \cdot 2) \\
{[>95]}\end{array}$ \\
\hline GalN $1 \mathrm{mM}$ & $23 \cdot 9(0 \cdot 6)$ & $12 \cdot 3(0 \cdot 6)$ & $\begin{array}{c}+4(0 \cdot 6) \\
{[<20]}\end{array}$ \\
\hline $\begin{array}{l}\text { GalN } 1 \mathrm{mM} \\
+\mathrm{U} 0.5 \mathrm{mM} \\
\operatorname{EGF}(20 \mathrm{ng} / \mathrm{ml})\end{array}$ & $\begin{array}{l}22 \cdot 5(0 \cdot 8) \\
{[100]} \\
6 \cdot 05(0 \cdot 5) \\
{[100]}\end{array}$ & $\begin{array}{c}15 \cdot 5(0 \cdot 8) \\
{[>95]} \\
5 \cdot 9(0 \cdot 3) \\
{[>95]}\end{array}$ & $\begin{array}{c}9 \cdot 5(0 \cdot 4) \\
{[>90]} \\
9 \cdot 5(0 \cdot 7) \\
{[>95]}\end{array}$ \\
\hline
\end{tabular}

Cell viability was assessed using trypan blue. After removing the medium $0.5 \mathrm{ml}$ of trypan blue $(0.2 \%$ in Hank's balanced salt solution) was added to each well and left for two minutes. The trypan blue solution was then removed and cells that had taken up trypan blue estimated by microscopy using a graticule. Values are the mean $(\mathrm{SD})$ of triplicate measurements.

Twenty four hours after partial hepatectomy, there was a $50 \%$ reduction in epidermal growth factor binding to liver plasma membranes with little change in epidermal growth factor receptor affinity, confirming previous observations. ${ }^{36}$ Epidermal growth factor binding to plasma membranes from livers of rats receiving $350 \mathrm{mg} /$ $\mathrm{kg}$ galactosamine was reduced by $35-60 \% 48$ hours after administration of the chemical, whereas the higher dose, of $800 \mathrm{mg} / \mathrm{kg}$, reduced epidermal growth factor binding by $>90 \%$ (Fig 2 and Table II). Galactosamine had no effect on the epidermal growth factor binding capacity of normal liver plasma membranes when included in the binding assay medium at $5 \mathrm{mM}$.

\section{IN VITRO EFFECTS OF GALACTOSAMINE DNA SYNTHESIS}

Exposure of hepatocytes to epidermal growth factor in combination with insulin resulted a

TABLE II Epidermal growth factor binding characteristics of plasma membranes from control and GalN-treated rats 48 hours after administration ${ }^{22}$

\begin{tabular}{lcc}
\hline Treatment & \multicolumn{1}{l}{ Bmax } & \multicolumn{1}{l}{$K d$} \\
\hline Control & $1656(64)$ & $493(41)$ \\
GalN $(350 \mathrm{mg} / \mathrm{kg})$ & $983(70)$ & $599(86)$ \\
GalN $(800 \mathrm{mg} / \mathrm{kg})$ & $776(81)$ & $1489(237)$
\end{tabular}

Bmax values are given in $\mathrm{fmol} / \mathrm{mg}$ membrane protein (SE) and those of the $\mathrm{Kd}$ in $\mathrm{pM}(\mathrm{SE})$. Data were derived using the GraphPAD computer program for curve fitting. marked enhancement of DNA synthesis assessed 26 hours later by ${ }^{3} \mathrm{H}$-thymidine incorporation. The addition of galactosamine $(1 \mathrm{mM})$ to the cultures reduced the basal (unstimulated) levels DNA synthesis and completely blocked DNA synthesis induced by the combination of insulin and epidermal growth factor (stimulated). Galactosamine at $0.5 \mathrm{mM}$ only partially reduced stimulated DNA synthesis. Uridine at a concentration which was not inhibitory to DNA synthesis $(0.5 \mathrm{mM})$ restored basal and stimulated DNA synthesis to control levels (Table III).

\section{VIABILITY AND EPIDERMAL GROWTH FACTOR} BINDING

Galactosamine at a dose of $1 \mathrm{mM}$ was directly toxic to primary hepatocyte cultures such that at 20 hours and 47 hours viability, as assessed by trypan blue exclusion was $70 \%$ and less than $20 \%$ respectively. In the presence of uridine $(0.5 \mathrm{mM})$ cell viability remained at control levels. There was a $56 \%$ reduction in ${ }^{125} \mathrm{I}$ epidermal growth factor binding after 47 hours of culture in galactosamine (Table IV). Uridine prevented the fall in epidermal growth factor binding.

\section{Discussion}

In this experimental study we have shown that 
liver plasma membranes isolated from animals in which galactosamine induced hepatic regeneration is occurring have a greatly reduced number of epidermal growth factor receptors. Sato $e a^{26}$ had addressed this question by indirect techniques, and shown by a perfusion system in intact liver that there was a reduced uptake of labelled epidermal growth factor by whole liver 48 hours after galactosamine treatment and also reduced epidermal growth factor binding by liver homogenates from galactosamine intoxicated rats. The study here clearly establishes the reduction in epidermal growth factor binding as a membrane event and avoids the inaccuracies caused by changes in volume of vascular compartments which may affect data derived from whole liver perfusion.

Broadly, two hypotheses could account for the reduction in epidermal growth factor binding by liver membranes from intoxicated rats. One possibility is that the galactosamine has directly or indirectly damaged the liver membranes, leading to loss of epidermal growth factor receptors. Alternatively, as occurs in the process of regeneration after partial hepatectomy, epidermal growth factor receptor internalisation may have occurred as an integral part of the process involved in initiating and modulating hepatocyte proliferation, a process probably reflecting production of TGF- $\alpha$ in the liver and binding of this ligand to the epidermal growth factor receptor. ${ }^{34}$ Our in vitro studies have excluded a direct effect of galactosamine on liver membranes, as when metabolic damage was prevented by the co-addition of uridine to cultures, the epidermal growth factor binding capacity of hepatocytes was unaltered and their ability to proliferate in response to the combination of insulin and epidermal growth factor was unimpaired. The possibility that secondary changes in the hepatocyte membrane occur after the intracellular effects of galactosamine cannot be excluded, however, and unsurprisingly dead cells have diminished epidermal growth factor binding capacity. The histological appearance of the liver from which membranes were extracted 48 hours after galactosamine administration, while showing unequivocal hepatitis, did not show massive hepatic necrosis. Our data show that reduced epidermal growth factor binding to membranes occurs even with low doses of galactosamine, which have led to only scattered necrosis of hepatocytes and minor liver damage as exemplified by small rises in transaminase concentrations. Sato et $a l^{26}$ comment that, in experiments in which doses of galactosamine twice those used in this study were administered, there was no significant reduction in the number of hepatic nuclei at 48 hours.

The experiments reported here therefore support the concept that regeneration after chemical damage to the liver involves similar mechanisms to those after partial hepatectomy at least with regard to the modulation of the epidermal growth factor receptor. The timing of the major change in epidermal growth factor binding, later than that occurring after partial hepatectomy, is compatible with the concept that it is loss of hepatic mass after administration of the chemical that is the stimulus to regeneration. It is of interest that similar changes in intrahepatic expression of the recently characterised hepatic growth factor occur in both toxic $\left(\mathrm{CCl}_{4}\right)$ and surgical induced damage of the rat liver, but again the changes in hepatic growth factor expression are earlier after hepatic resection than after chemical damage. ${ }^{27}$ Such findings suggest that observations on the control of hepatocyte proliferation derived from the partial resection model may be extrapolated to the more complex problems of repair after chemical or viral hepatitis which are more relevant to disease in man.

1 Alison MR. Regulation of hepatic growth. Physiol Rev 1986; 66: 499-541.

2 Michalopoulos GK. Liver regeneration: molecular mechanisms of growth control. FASEB F 1990; 4: 176-87.

3 Earp HS, O'Keefe EJ. Epidermal growth factor receptor number decreases during rat liver regeneration. $\mathcal{F}$ Clin Invest $1981 ; 67$ 1580-3.

4 Gruppuso PA, Mead JE, Fauto N. Transforming growth factor receptors in liver regeneration following partial hepatectomy in the rat. Cancer Res 1990; 50: 1464-9.

5 Wollenberg GK, Harris L, Farber E, Hayes MA. Inverse relationship between epidermal growth factor induced proliferation and expression of high affinity surface epidermal growth factor receptors in rat hepatocytes. Lab Invest 1989; 60: 254-9.

6 Francavilla A, Ova P, Polimeno L, Sciascia C, Coetzee ML, Starzl $\mathrm{TE}$. Epidermal growth factor and proliferation in rat hepatocytes in primary culture isolated at different times after partial hepatectomy. Cancer Res 1986; 46: 1318-23.

7 Rubin RA, O'Keefe EJ, Earp HS. Alteration of epidermal growth factor-dependant phosphorylation during rat liver regeneration. Proc Natl Acad Sci USA 1982; 79: 776-80.

8 Okamoto M, Karasik A, White MF, Kahn CR. Epidermal growth factor stimulates phosphorylation of a 120 -kilodalton endogenous substrate protein in rat hepatocytes. Biochemistry 1990; 29: 9489-94.

9 Marquardt H, Hunkapillar MW, Hood LE, Twardzik DR, DeLarco JE, Stephenson JR, et al. Transforming growth factors produced by retrovirus-transformed rodent fibroblasts and human melanoma cells: amino acid sequence homology with epidermal growth factor. Proc Natl Acad Sci USA 1984; 80: 4684-8.

10 Massaque J. Epidermal growth factor-like transforming growth factor. F Biol Chem 1983; 258: 13614-20.

11 Mead JE, Fausto N. Transforming growth factor alpha may be a physiological regulator of liver regeneration by means of an autocrine mechanism. Proc Natl Acad Sci USA 1989; 86: $1558-62$.

12 Rall LB, Scott J, Bell GI, Crawford RJ, Penschow JD, Niall HD, et al. Mouse prepro-epidermal growth factor synthesis by kidney and other tissue. Nature 1985; 313: 228-31.

13 Decker K, Keppler D. Galactosamine induced liver injury. In: Popper H, Schaffner F, eds. Progress in liver diseases. Vol IV. New York: Grune and Stratton, 1972: 183-99.

14 Nakata R, Tsukamoto I, Miyohi M, Kojo S. Liver regeneration after carbon tetrachloride intoxification in the rat. Biochem Pharmacol 1984; 34: 586-8.

15 Keppler D, Lesch R, Reutler W, Decker K. Experimental hepatitis induced by D-galactosamine. Exp Mol Pathol 1968; 9: 279-90.

16 Keppler D, Decker K. Studies on the mechanism of galactosamine hepatitis: accumulation of galactosamine-1-phosphate and its inhibition of UDP-glucose pyrophosphate. Eur F Biochem 1969;

17 Savage CR Jr, Cohen S. Epidermal growth factor and a new derivative. Rapid isolation procedures and biological and chem cal characterization. F Biol Chem 1972; 247: 7609-11.

18 Higgins GM, Anderson RM. Experimental pathology of the liver: restoration of liver of white rat following partial surgical removal. Arch Pathol 1931; 12: 186-202.

19 Berry MN, Friend DS. High yield preparation of isolated rat liver parenchymal cells: a biochemical and fine structural study. $\mathcal{F} \mathrm{Cel}$

20 Selden C, Hodgson HJF. Further characterisation of hepatotropin, a high molecular weight hepatotropic factor in rat serum. f Hepatol 1989; 9: 167-76.

21 Aronson NN, Touster O. Isolation of rat liver plasma membrane fragments in isotonic sucrose. Methods Enzymol 1974; 31:

22 Hubbard $\mathrm{AL}$, Wall DA, Ma A. Isolation of rat hepatocyte plasma membranes. 1. Presence of three major domains. $\mathcal{F}$ Cell Biol 1983; 96: 218-29.

23 Schacterle GR, Pollack RL. A simplified method for quantitative assay of small amounts of protein in biological material. Anal Biochem 1973; 51:654-5.

24 Vessey DA, Cunningham JM, Selden AC, Woodman AC, Hodgson HJF. Dimethyl sulphoxide induces a reduced growth rate, altered cell morphology and an increased EGF binding in Hep $\mathrm{G} 2$ altered cell morphology and an ince
cells. Biochem f 1991; 227: 773-7.

25 Munro HN, Fleck A. The determination of nucleic acids. Method Biochem Anal 1966; 14: 113-76.

26 Sato H, Sugiyama Y, Kim DC, Yanai S, Kurita M, Fuwa T, et al. Decrease in the number of receptors for epidermal growth facto in the liver of D-galactosamine-intoxicated rats. Biochem Pharmacol 1989; 38: 2663-71.

27 Selden AC, Jones M, Wade D, Hodgson HJF. Hepatotropin mRNA expression in human foetal liver development and in live regeneration. FEBS Letts 1990; 270: 81-4. 